\title{
Devotional Islam and Sound Reproduction
}

One evening in 2011, I was sitting in the living room of Raouf, a retired school inspector in a town in northern Mauritius. Raouf's twenty-one-year-old nephew Naushad was also there. Naushad worked in his family's retail business in a major tourist center on the northern coast while also studying at the University of Mauritius. I had wanted to talk to him for a while because I had heard that he used to organize mahfil-e mawlud, the ritual event that features recitation of na't poetry. Although not a well-known na't khwan himself, he had learned to recite na't and told me about how he began doing so.

It started more than ten years ago with the large video camera of a cousin of my father. He used to make recordings of weddings with it. Then I wanted to try out the camera myself and started filming. It was not easy, as the camera was very heavy. I began filming an Urdu drama, and we made videotapes of it. Together with a cousin of my mother, I went toward religion [kote din], and we filmed mahfils in different mosques in the north [of Mauritius]. I got a new camera, from which you could make DVDs, so I filmed majlis and mahfils in our madrassa, or in other mosques, and distributed the DVDs among my friends and, after Friday prayers, at mosques for fifty rupees. I bought a digital projector for our mosque and also recorded a conference of the Ahle Sunnat. Then I realized I need an amplifier for the sound. I became very interested in sound systems and listened a lot to sound recordings of mahfil-e mawlud. I started getting into na't through listening to recordings. "Madina, Madina" was the first na't I was able to recite. A group of friends and I met regularly, listening to recordings, writing down the poetry from cassettes and CDs, and making programs for mahfils we organized.

Naushad's account of how he became fond of na't to the point of learning to recite the poetry and organizing mahfils himself highlights how the cultivation of this 
poetic genre and contemporary media practices have become inseparably linked. For him, listening to na't has become a regular routine that he has built into the rhythms of his daily life. "Most of my friends listen to Western and Indian music. Maybe 20 percent listen to na't. For many there is a balance: they listen to na't and also to different kinds of music. I listen to na't for inspiration, in the early morning, alone in the bus on the way to the university. I get into the na't .... I also listen to na't in the car together with friends."

Naushad pointed out how newer media practices have loosened the link between immersing oneself in the recitation of na't and the established ritual contexts and times of mahfils. For him and his friends it is possible to saturate routine daily situations with nat, to enjoy inspiration from it, as he put it. I had many conversations with my Mauritian Muslim interlocutors about what Naushad called the inspiration of nat, and they repeatedly told me how they felt captivated and deeply moved when listening to recitations of the poetry.

Shareef had a particular way of describing what Naushad had called the inspiration gained by listening to nat. I had first met Shareef in 2003, at the suggestion of several of my interlocutors. He was known as one of the pioneers among the circle of Mauritian nat khwan who had started to make recordings of na't recitations and distributed them on cassettes and, later, also on CDs. In a conversation when I again visited his home in a village in the central part of the island in 2010, he stressed that the best na't recitations are the ones that are "touching," evoking the synesthetic effect of listening as the bodily sensation of touch. When I asked him when makes a na't touching, he replied,

A na't evokes feelings for the Prophet. For example, we are here, he is there, and there is no way to get where he is. So there is a feeling of separation, of being cut off. We long for him and wonder how to get to the place where he is. This is why a na't is touching. Also, when we recite a na't, we sometimes evoke his [the Prophet's] difficult moments. When he prayed at the $k a^{\prime} b a$, people threw stones at him. Nobody believed him. He had no food, because he gave everything to the poor. We also recall the miracles the Prophet brought about. Also the na't is in Urdu and not in Creole. Urdu is simply the language of the poet. It has more intense words. Also, the voice of the na't khwan needs to be melodious, like that of a Qari [Qur'an reciter]; it needs to be well formed, with fluctuation. A na't in Urdu recited with a good voice touches you directly.

In this quote Shareef pointed to several dimensions of how a nat recitation can be touching. A narrative of separation and longing can move listeners deeply, as do accounts of the Prophet's initial difficulties in creating the first community of Muslims or of his generosity to the poor. The choice of linguistic code is also very important. For Shareef as for many others, Urdu is associated with ideas of poetic beauty and power. According to him, the main vernacular language, Mauritian Creole, lacks these qualities in comparison. Further, the voice of the reciter needs to be properly trained so that the recitation is performed with the right vocal 
qualities. As I will show, my Mauritian Muslim interlocutors directly connected qualities of the voice to the power and effects of a recitation of nat, especially the effect that Shareef described as the sensation of being "touched."

Trying to trace such peculiar powers of the voice, I investigated uses of CD recordings of the Islamic devotional genre na't in Mauritius and its role in shaping performances of this genre at religious speech events known as mahfil-e mawlud, which took place on occasions such as ritual commemorations and weddings. Na't (from the Arabic $n a^{\prime} t$, meaning "description, qualification, characterization") are devotional poems recited in praise of the Prophet Muhammad and of what is often considered his favorite city, Madina. They are also performed alongside poetry in praise of other Muslim authorities, such as the prominent Sufi teachers Mu'inuddin Chishti (d. 1235, popularly known as Khwaja Gharib Nawaz) and 'Abd al-Qadir Jilani (d. 1166), and even members of the ahl-e bayt (the family of the Prophet and their descendants), such as the Prophet's son-in-law 'Ali and his grandson Husayn, a practice recalling Shi' ite traditions. This genre-which in Mauritius is associated with the Sunni South Asian Ahl-e Sunnat wa Jama'at (people of the Prophet's way, and the majority community), and whose practice is vigorously opposed by followers of the Deobandi and Salafi traditions-is usually performed in Urdu. Its performance is, above all, considered an act of piety that has a transforming effect on subjects; but it is also understood as helping to link a diasporic Mauritian Muslim community to sources of religious authenticity from a location on the periphery of the Muslim world.

Electronic reproduction of this genre is significant because of the authority associated with recordings of nat by accomplished performers from India and Pakistan, as well as by Mauritians who have received training from such performers. In addition, the performance of nat is a practice of intercession that can be understood as mediating between subjects and an otherworld. Against this background of religious practice as a particular form of interaction, sound reproduction also intervenes in a fundamental way in the process of mediation between what are experienced as different ontological spheres. The use of first cassette and later CD recordings of na't reveals a particular relationship between this form of electronic mediation of discourse and recital, questions of religious and diasporic authenticity, and the performance of nat understood as a practice of mediation between subjects and an otherworld. In particular, I suggest that a close articulation exists between critiques of mediation in Islamic traditions, such as those expounded in debates between Deobandi- and Ahl-e Sunnat-affiliated Muslims, and certain uses of electronic voice mediation, such as the circulation of cassette and CD recordings of na't. Specifically, a key formal property of electronic mediation, the minimizing of spatial and temporal distances in interaction, intersects with a particular authority of voice in religious tradition. The significance of electronically reproduced nat emerges in the ways in which sound reproduction becomes part of a preexisting genealogical logic of Islamic authority, in which 
the faithful transmission of religious discourse through long chains of reliable interlocutors traceable to the Prophet Muhammad and his companions plays a central role. ${ }^{1}$

\section{MUSLIMS IN MAURITIUS: CONTESTS OVER RELIGIOUS AUTHORITY IN THE DIASPORA}

Mauritius is a former plantation colony in which nearly 70 percent of the population of approximately 1.3 million is of South Asian origin. Muslims of Indian origin make up 17 percent of the population. Like other Mauritians, they primarily use French-lexifier Mauritian Creole in everyday conversation, use English in education and state administration, are embedded in a strongly francophone mediascape-French also being the dominant language of the private-sector economy-but also cultivate Urdu and, to a lesser extent, Arabic as ancestral languages. These ancestral languages are never used in everyday interaction but are taught on an ethnic basis in state schools and are important emblems of ethnoreligious belonging. Mauritian state institutions, in general, strongly encourage the cultivation of "ancestral cultures" and ancestral languages of different ethnicities. Under the leadership of the middle class among Hindus (52 percent of the population), who dominate state institutions, a hegemonic notion of cultural citizenship has been established, according to which Mauritians are subjects with origins in other parts of the world and continuing commitments to diasporic ancestral cultures. Accordingly, full membership in the Mauritian nation is performed by cultivating ancestral traditions, whose perceived authenticity provides crucial support for claims to a legitimate place within the nation (Eisenlohr 2006a, 2007). For Mauritian Muslims, Islamic traditions represent the official ancestral culture through which their membership in a Mauritian nation is defined. Thus, contests over the authenticity and purity of Islamic traditions are not just theological arguments or power struggles between representatives of different schools of thought but are also about claiming a legitimate place for Muslims in Mauritius, which is ensured by the projection of a Muslim ancestral culture deemed to be authentic. ${ }^{2}$

Although some Muslims from India lived in Mauritius under French colonial rule (1715-1810), the vast majority of Mauritian Muslims today are the descendants of North Indian indentured laborers of mostly humble agricultural background who arrived in British colonial Mauritius between 1834 and the First World War to work on the island's sugar plantations. Small groups of Indian Muslim traders of Gujarati background also established themselves as free immigrants in Mauritius, in the second half of the nineteenth century (Kalla 1987). These trader immigrants, aided by their capital and their intense and ongoing links with India, played the role of mosque builders and founders of Islamic institutions on the island. The Kutchi Memons, a trader caste originally from the western part of Gujarat, soon emerged as the dominant force in spreading forms of Islam more institutionalized 
than those practiced by most of the poor rural indentured laborers and their descendants. They gained control over the island's principal mosque in the colonial capital of Port Louis in 1908 after a long and bitter lawsuit against their chief competitors, the Sunni Surtees (Vorahs), another Gujarati Muslim trader caste.

In the 1920 s and 1930s, the Kutchi Memons increasingly cultivated links to scholars and institutions of the Ahl-e Sunnat tradition in India. The scholar of Islamic law ('alim) and Ahl-e Sunnat missionary Abdul 'Alim Siddiqi visited Mauritius at the invitation of the Memons for the first time on a return journey to India from South Africa in 1928, and he repeatedly returned in the following years, once for a nine-month mission in 1932-1933, attracting large crowds at his public discourses $\left(v a^{\prime} z\right){ }^{3}$ Because of the influential position of the Memons as an elite among Mauritian Muslims, and because of their connections to the Ahl-e Sunnat network, this tradition became the predominant current of Islam in the first half of the twentieth century throughout Mauritius. ${ }^{4}$

The Ahl-e Sunnat is one of the movements of Islamic reformism that emerged in the second half of the nineteenth century in colonial India (Metcalf 1982, Sanyal 1996, Reetz 2006). It was founded by the 'alim Ahmad Riza Khan Barelwi (18561921) and is also known as the Barelwi tradition after the North Indian town of Bareilly, a seat of Islamic learning and the residence and ancestral home of the movement's founder. In contrast to other contemporary Sunni reform movements, such as the school of Deoband, the Ahl-e Sunnat's vision of Sunni Islam distinguishes itself by its great emphasis on the veneration of saints, its openness to Sufism, and the importance it places on spiritual intercession by saintly figures.

The Ahl-e Sunnat is often mistaken as representative of a "popular" or "traditional" South Asian Islam largely untouched by the wave of reformism in Indian Islam since the nineteenth century. The movement emerged in a context in which many of the devotional practices of its followers came under attack as backward and inauthentic by other, better-known reform movements, such as the school of Deoband and the Ahl-e Hadith (Metcalf 1982). Responding to such attacks, Ahmad Riza Khan Barelwi systematically sought to give the mediatory practices common in South Asian Islam a new legitimacy and scriptural foundation. At the same time, he made use of the emerging print media and modern transport systems in his endeavor to propagate a new synthesis between 'ulama-based Islam and Sufi traditions, which he claimed best emulated the original society of the Prophet. The Ahl-e Sunnat should, thus, be understood as a reformist movement on a par with the other representatives of renewal (tajdid) in late nineteenth-century Indian Islam (Sanyal 1996). For his followers, of course, Ahmad Riza Khan Barelwi was the foremost renewer (mujaddid) of Islam of his age. Barelwi is a label ascribed by others to the movement and is usually rejected by followers of the Ahl-e Sunnat in South Asia, who refer to themselves by the latter label. In Mauritius, the label Barelwi is rarely used, and Mauritian Muslims who are affiliated with the Ahl-e Sunnat say they are affiliated with the "Sunnat Jama'at" or more commonly state that they are simply "Sunnis." 
The Ahl-e Sunnat tradition entertains a close relationship with the Sufi order (tariqa) of the Qadriyya and highly venerates its spiritual founder, 'Abd al-Qadir Jilani, who is also addressed and eulogized in numerous devotional poems. In particular, scholars of the Ahl-e Sunnat tradition are known for their teachings on the Prophet Muhammad, often summed up as the doctrine of present and observant (hazir-o nazir). Whereas God is beyond space and time, according to this controversial interpretation, the Prophet Muhammad is no ordinary human being but is manifest as pure light (nur-e muhammadi) while he is spiritually present and perceptive, when pious Muslims invoke him and ask for blessings on him. Even long after his death, the Prophet thus continues to be a powerful spiritual presence, capable of mediating between Muslims and God. The reading of na't and the recitation of blessings directly bring about his presence to the benefit of the believer ( $\left.\mathrm{mu}^{6} \mathrm{~min}\right) .^{5}$ The deep personal devotion to the Prophet that is so characteristic of the Ahl-e Sunnat tradition resonates with the broader theme in Sufi traditions of attaining an intimacy with God through emulating the Prophet (Buehler 1998, Schimmel 1975). In Sufi traditions a preferred method for attaining this goal is to perform spiritual exercises under the guidance of a Sufi sheikh in order to establish a "heart-to-heart connection, leading to a vividly intense experience of Muhammad" (Buehler 1998: 17). As it aims to bring about the spiritual presence of the Prophet, the recitation of na't is in direct continuity with such Sufi traditions.

A main competitor of the Ahl-e Sunnat, as noted, is the school of Deoband, another reformist tradition placing emphasis on a purist "return" to what it considers the authentic sources of Islam. Deobandis also tend to be greatly suspicious of illicit innovation (bid'a), especially in the South Asian setting, in which Islam is not the overall dominant religious tradition. In particular, the Ahl-e Sunnat's emphasis on practices of intercession has been attacked by Deobandis as an illegitimate innovation that negates the oneness of God (tawhid) by elevating other transcendent mediators to a position next to God. They charge that followers of the Ahl-e Sunnat thus commit the unforgivable sin of shirk, or the setting up of partners or associates in the worship of God.

The 1950 s saw a broad establishment of Deobandi-affiliated missionizing and institution-building in Mauritius. First, in 1954, the Sunni Surtees completed the building of their Markazi Mosque in Port Louis, intended not only as a social counterweight to the Memon-run Jummah Mosque but also as the local center of an intensifying relationship between the Surtees and Deobandi scholars and institutions of learning in India. Thus, the conflict between Barelwis and Deobandis in Mauritius was, at the beginning, also related to the antagonism between the Kutchi Memons and the Sunni Surtees. Then, in 1959, a disciple of Maulana Abul Ala Maududi in Pakistan, the founder of the Jama'at-e Islami, a pioneering movement of modern Islamism that also traces its origins to the tradition of Deoband, cofounded the Islamic Circle of Mauritius. ${ }^{6}$ Finally, and most importantly, the Deobandi missionary movement Tabliqi Jama'at arrived in Mauritius, cultivating 
a close relationship with the Surtees. Initially using the Markazi Mosque as an unofficial headquarters, it quickly gained a steadily growing number of followers among Muslims of all classes and ethnic backgrounds. The Tabliqi Jama'at established its own center in Port Louis in the early 1990 .

Thus, in present-day Mauritius, the Deobandi tradition is, above all, represented by the Tabliqi Jama'at, today often considered the world's most powerful transnational Islamic missionary movement and sometimes described as similar in scope to global evangelism (Sikand 2002, van der Veer 2002). When the Tabliqis started to establish themselves in Mauritius in the 1950s, the local Islamic environment was still heavily dominated by the Ahl-e Sunnat. Since the 1970s, however, the Tabliqi Jama'at has made serious inroads into the Ahl-e Sunnat constituency in Mauritius, to the extent that most Muslims now hold that the Tabliqis are close to dominating the cities and urban areas, whereas the hegemony of the Sunnis (the Ahl-e Sunnat followers) has shrunk to the small towns and villages of the countryside.

As a result of this conflict, practices of worship have come under increasing scrutiny and debate by an increasingly well-informed and educated Muslim public in Mauritius. Tabliqis often portray the Ahl-e Sunnat as representatives of a popular Islam favored by superstitious and innocent country folk blindly following spiritual mediators. More particularly, they claim that the practices of intercession favored by the Ahl-e Sunnat are illegitimate additions to Islamic practice attributable to the Indian (and, by implication, Hindu-dominated) environment in which they arose. Although Tabliqis often claim to follow no particular tradition or school of thought, the Tabliqi Jama'at is closely linked to the tradition of Deoband, in which its chief ideologue, Muhammad Zakariyya (1898-1982), was trained. Zakariyya subsequently also taught at a branch seminary of Deoband. The Tabliqi Jama'at promotes a "return" to the society of the Prophet as a model to be practically emulated (Gaborieau 1997, Metcalf 1993, Sikand 2002). Thus, the struggle over religious authority also involves attributions of authenticity, in which not only is the diasporic status of Mauritian Muslims problematized but also their origins in India are subject to a skeptical assessment on the basis of perceived Islamic authenticity. ${ }^{7}$

Ahl-e Sunnat-affiliated Muslims often find themselves on the defensive in these struggles, in which conflicts over religious authority and diasporic authenticity are frequently intertwined. In the last five decades, the Ahl-e Sunnat camp has steadily lost followers to the proselytizing efforts of the Tabliqi Jama'at. One of the key points of contestation between followers of these two traditions is the performance of certain devotional genres-above all, na't. These conflicts touch on long-standing differences regarding the role of spiritual mediation in Islamic traditions, as well as on disputes with respect to the cultivation of affective stances and dispositions in leading a pious life. Thus, among Muslims in Mauritius, the legitimacy of practices of intercession such as performing and listening to na't has increasingly come under pressure. 


\section{SOUND REPRODUCTION AND DEVOTIONAL GENRES}

Although nat has for a long time formed part of Mauritian Muslims' religious practices, its prominence, ways of dissemination, and uses have recently changed. Apart from a small number of devotional poems and songs known as part of an oral tradition by many Mauritian Muslims, nat were known, until the last few decades, solely from "old books" from India written in Urdu. Just a few copies were available in Mauritius, and they were accessible only to the relatively few individuals with sufficient competence to read Urdu. Since the 1980 s, however, na't cassette tapes and, subsequently, CDs from India and Pakistan have become widely available. At the same time, talented performers in Mauritius began recording and disseminating their own collections of nat, supported by Indian and Pakistani imams affiliated with the Ahl-e Sunnat tradition. Also, regular Mauritius Broadcasting Corporation radio broadcasts of na't performances began in the mid-199os, and some listeners record them and then transcribe them by hand. Although nat are not locally composed in Mauritius, a task that is often described as exceedingly difficult because of the perceived danger that praising the Prophet and saintteachers can slip into idolatry, local performers have closely collaborated with Indian imams residing in Mauritius who are affiliated with Barelwi institutions in India to study na't and to learn how to perform na't "correctly" and authoritatively.

An important aspect of the practice of na't in Mauritius is that audio recordings and their circulation and dissemination are firmly integrated with literacy practices. Mauritian Muslims interact with these recordings in the following ways: They typically listen to them on the radio in the morning at home or in the car and use them to prepare for mahfil-e mawlud on particular occasions, such as the anniversary of the demise of a saint ('urs) or the birthday of the Prophet Muhammad (miladun nabi), as well as weddings and other key events in life. Often, persons preparing a mahfil-e mawlud carefully transcribe the text of nat in roman letters from a recording and then make photocopies of these handwritten notes to distribute to those taking part in the event. Given this continuity with practices of literacy, local performers have released printed booklets of texts of na't simultaneously with their cassette and CD recordings of collections of nat. The Urdu text of a nat is usually presented in nastaliq writing (the variant of the Arabic script used for Urdu) on one page and, on the opposite page, a transliteration in Roman letters with a French translation running underneath. Often, the transliterated pages in these booklets, and copies of handwritten transliterations made individually from audio recordings, either purchased or recorded from radio programs, are used simultaneously in mahfil-e mawlud. Nevertheless, the printed booklets of na't texts and translations are clearly used as supplements to audio recordings of the genre, which, in their aesthetic and spiritual qualities, are considered the actual models to be emulated.

Local, accomplished nat performers have recently come to play an important role in the legitimatization and popularization of nat as a devotional practice 


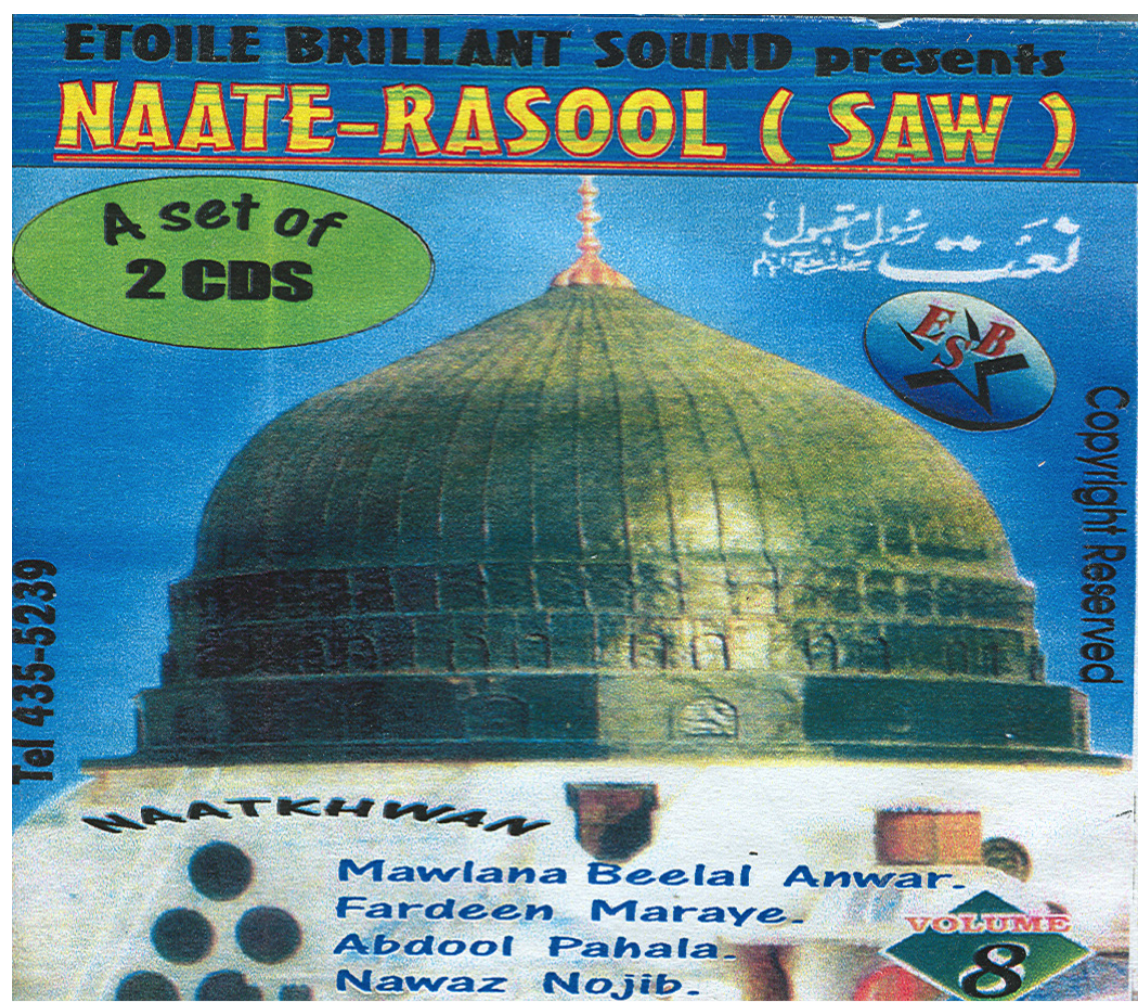

FIGURE 1. Mauritian CD cover of a collection of nat recordings. Photograph by the author.

through circulation of electronically mediated na't. As I mentioned, Shareef is a well-known local performer and producer of na't cassettes and CDs in Mauritius. He is a schoolteacher, now the head of a primary school, and previously directed a local mosque association (jammat in Mauritian Creole) in his village in the central region of the island. Shareef started to develop his talent in the performance of na't with the assistance of the Indian maulana Bashir Ahmad Na'imi. Na'imi lived in Mauritius as the imam of the Ashrafi Mosque in the central village of Providence, later became head of the Aleemia College, an Islamic secondary school in the town of Phoenix, and now, after his return to India, heads an Islamic academy (dar-al 'ulum) in Uttar Pradesh. For Shareef, Maulana Na'imi was a main source of na't, enabling Shareef to build up his repertoire while Maulana Na'imi also assisted him in training his voice and interpreting the spiritual significance of nat. The teaching and recitation of na't is frequently part of curricula of Ahl-e Sunnat-affiliated madrassas and dar-al 'ulum in India and Pakistan. After Maulana Na'imi's return to India, Imam Shamim al-Azhari of Allahabad, India, a graduate of al-Azhar in Cairo and a former imam of the Jummah Mosque in Port Louis, took over the role 

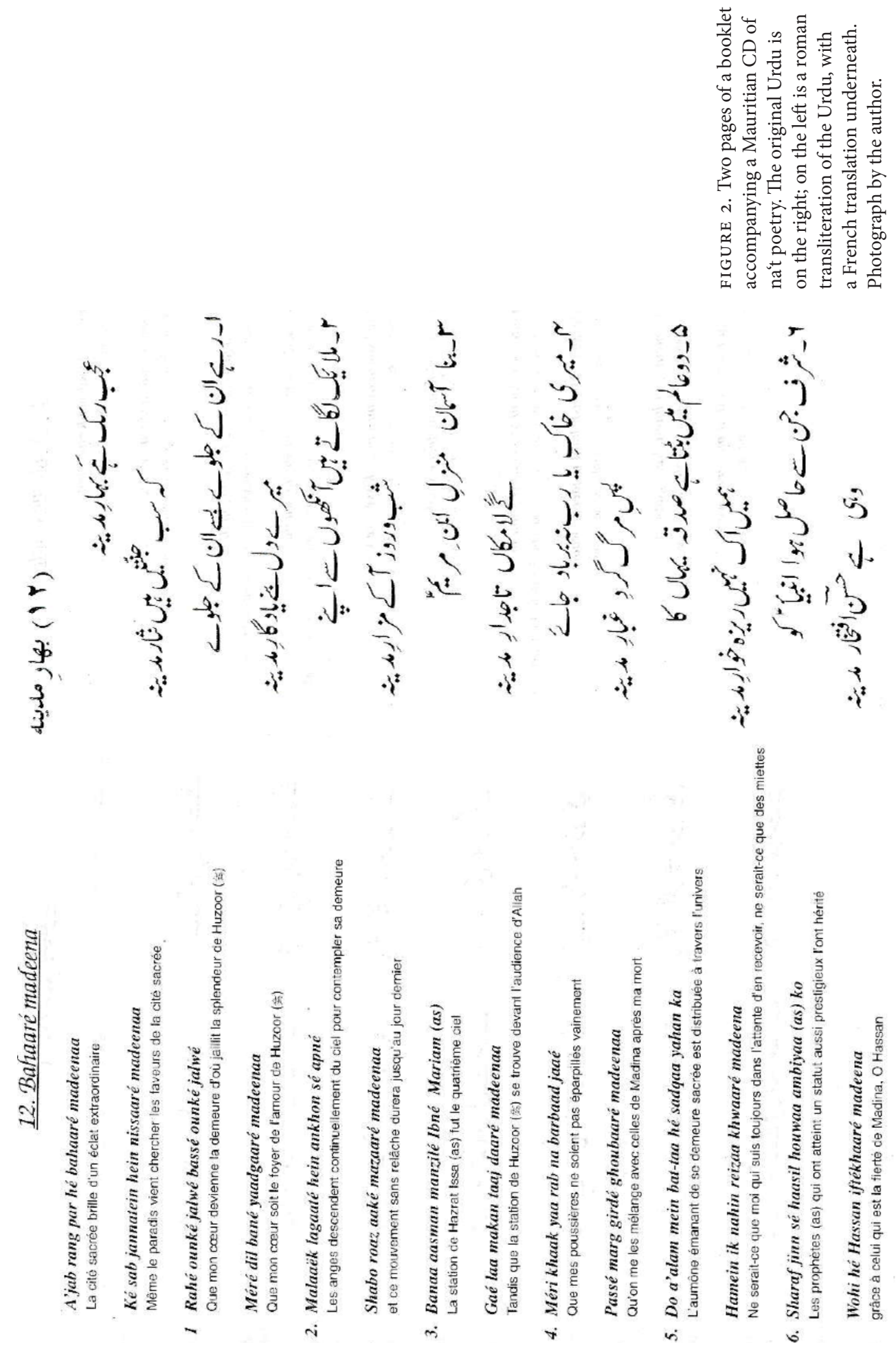
of Shareef's mentor. Candidates for the position of imam of the Jummah Mosque were traditionally recommended to the mosque association by Maulana Shah Ahmad Nurani in Pakistan. ${ }^{8}$ This close collaboration with Indian Ahl-e Sunnataffiliated imams has enabled Shareef to release nine cassettes and CDs with accompanying booklets, which are widely circulated among Muslims in Mauritius and are among those most frequently consulted and listened to by Muslims preparing for a mahfil-e mawlud to be held in a home or a mosque.

\section{RELIGION AS MEDIATION, AND THE POWER OF REPRODUCED NA'T}

The recitation of na't is a form of religious practice designed to produce a range of performative effects. First, the practice of na't is expected to transform the soul of the subject, imbuing one with love for and emotions of attachment to the Prophet. $\mathrm{Na}$ ' $\mathrm{khwani}$ is a tradition of verbal art in which performers are judged according to how intensely they move emotions and how their voices stir attachment to and love for the Prophet Muhammad in listeners. Thus, na't is a key practice in a theory of intercession. In it, performers praise, declare their love for, and ask for blessings for intermediaries between themselves and God, such as the Prophet Muhammad, and through other poetic genres also for 'Abd al-Qadir Jilani, Ghareeb Nawaz, and members of the ahl-e bayt. Performing na't is a way to accumulate spiritual merit (sawab) and, thus, constitutes a means to turn performers and other participants in a mahfil-e mawlud into morally improved persons. In the eyes of its advocates, na't is a performative technique to "rouse in the soul an overwhelming desire to invoke blessings and salutations upon him [the Prophet]" (Kabbani 2002: 69). Na't is, therefore, a performative practice also in the sense of creating pious dispositions in the participating subjects (Hirschkind 2006). The practice is a component of a larger complex of pious behavior, adab, promoted as a model for an ideal Muslim subject by Ahmad Riza Khan Barelwi, who, apart from being a prolific theologian and jurisprudent, was also known as an accomplished composer of na't (Sanyal 1996: 13). Na't and other practices of intercession are often labeled traditional components of a popular South Asian Islam. Ahmad Riza Khan Barelwi, however, saw himself as a reformer and understood the practice of na't as part of a wider renewal of Islam (tajdid) in colonial India, a concern he, of course, shared with members of other Islamic movements of his day. The performance of na't moves the mediator to intercede on behalf of the performing subject, and, at the same time, it attracts to the performer-participant the spiritual merit necessary for the balancing of one's sins.

The use of sound reproduction in the practice of the long-established genre of nat has become common, with recordings from Pakistan and India and local productions circulating widely among Muslims in Mauritius. At the same time, "live" recordings of visiting master na't khwan from India and Pakistan were first 
distributed on tapes and then CDs. ${ }^{9}$ Technologies of sound reproduction are used for preparing a mahfil-e mawlud, or making a "program," as my interlocutors say. At the same time, nat recorded on cassettes and CDs have also enabled new contexts for audition, such as listening to nat in the car or at home with family members and friends or alone. Na't sound files can be downloaded from several Islamic websites based in Pakistan, India, and the United States (Alahazrat.net n.d., Naatsharif.com n.d., islamicacademy.org n.d.) and are an additional way of listening to na't in Mauritius outside of established contexts of performance.

Before the use of na't recorded on cassettes and CDs, local imams were the main source of na't, and they kept collections of na't, transcribed in Urdu, in mosques. The popular Urdu language manual Milad-e akbar (cf. Hermansen 1995, Qureshi 1996: 55) was also well known in Mauritius as a compilation of na't, and it included instructions on how to recite them, explanations of the benefits derived from this act, and practical instructions on how to hold a mahfil-e mawlud. Even though Urdu has been taught as an ancestral language to students of Muslim background in Mauritian schools since the 1930s, most Mauritian Muslims do not possess sufficient Urdu literacy skills to read the na't, although, clearly, most Muslims I know in the towns and villages I worked in understand the texts when they are recited. In this context, cassettes and CDs have newly popularized na't, making the poetic genre accessible to people who lack reading knowledge of Urdu.

At the same time, recorded performances by accomplished na't khwan are now understood as authoritative models to emulate. Mauritian Muslims following the Indian Ahl-e Sunnat tradition stress the importance of performing na't in the right way, which, in particular, should not remind listeners of Hindi film songs, should incorporate the correct pronunciation of the Urdu, and should feature the "right" version of nat. The latter concern is especially important because, in expressing profuse praise of the Prophet, na't is a delicate, controversial genre that, in the eyes of most Muslims, must never suggest equivalence between the Prophet and God. As one imam in a village in northern Mauritius put it, composing na't is like walking on the blade of a sword, and thus, it pushes the limits of what is considered proper Islamic practice on several counts. The recordings reassure many Mauritian Muslims that reciting and appreciating na't is not a matter of ignorance about proper Islamic conduct in the diaspora or an unwarranted perpetuation of the ways of ancestors who may not have been knowledgeable about scriptural Islamic traditions when they arrived as indentured laborers in Mauritius. Scholars working in the Ahl-e Sunnat tradition have, for a long time, cited hadith supporting the claim that performing na't was a common practice among the companions of the Prophet and was also highly appreciated by him, The circulation of first tapes, and then CDs, from India and Pakistan, and their production in Mauritius under the guidance of imams from South Asia, have convinced many Muslims that na't is, indeed, an authentic and authoritative practice in the Muslim world beyond Mauritius. 
In this sense, the great concern about the correctness and faithful reproduction of na't that partly motivates the use of sound reproduction evokes a "recitational logocentrism" attested for other Islamic traditions (Messick 1993: 21-25; see also Lambek 1990). At the same time, this recitational logocentrism has a key performative dimension because the authentic presence of the "correct" text, enabled through long chains of dialogues, is the precondition for its performative efficacyhere, its transformative effects on pious subjects and its successful enactment of spiritual intercession. Attributions of authorship are of key significance, because the recitation of na't is interpreted as a merging of the performer's voice with an authorial voice ensuring the authenticity of the poetry. Even if performing na't does not directly summon a divine presence, as the recitation of scripture does, it at least evokes the presence and authorship of learned personalities and religious authorities like Ahmad Riza Khan Barelwi as creators of na't, ensuring the appropriateness and efficacy of the recited poetry. At the same time, the faithful reproduction of na't, which many see as enhanced by the use of techniques of voice mediation, exceeds the "correct" transmission of spiritual knowledge because it also involves the mediation of a visceral experience of piety and personal closeness to Islamic authorities, which, in the performance of na't, are interdependent dimensions of the event. This continuity, crucial for both the authenticity and performative efficacy of na't, is, in turn, something many see more faithfully realized through mediation by voice rather than writing. This is an important aspect of my interlocutors' stress on the necessity to preserve the "proper meaning" of na't and on the potential dangers arising from a failure to do so in a chain of performative entextualizations (using the term coined by Briggs and Bauman [1992]) and recontextualizations.

Technologies of sound reproduction are important in the faithful transmission of a particular performative style, which is as significant for the efficaciousness of na't as for the authoritative transmission of texts. When I asked my interlocutors how one could tell whether na't was recited well, many of them negatively defined what a "good" na't is by contrasting it with Hindi film songs, since in Mauritius the consumption of "Bollywood" entertainment is ubiquitous. ${ }^{10}$ Shareef, for example, described the struggle against what he sees as the influence of the music of popular Hindi films on the performance of na't as one of his main motivations to become a widely known na't khwan and disseminate his own recordings: "Earlier Muslims in Mauritius did know the words of na't from imams and old people, but many did not know how to read na't correctly. They would simply recite the lines they remembered to the melodies of film songs they heard during the day, and would not keep the proper restraint and respect and would spoil everything. I did not want film songs to be used for na't, and this is why I wanted to give guidance."

The performative style of na't that Shareef aspires to is demarcated from film songs in numerous ways. It includes no use of musical instruments and no female voices, unless the occasion is a mahfil for women only. Also, in contrast to 
performances of Hindi film songs, the speed of the delivery should always be moderate and not overtly rhythmic, and the performer should guard its recitational qualities. In other words, the recitation of nat should be performed in iconic correspondence to the decorum, the restrained and respectful conduct and absence of agitation, that many conceive as a distinctive characteristic of a pious Muslim. For Shareef, the faithful transmission of this particular performative mode is best ensured through sound reproduction, because this dimension cannot be mediated through mere knowledge of the printed texts. There are not enough accomplished na't khwan in Mauritius to provide effective guidance without mass mediation to counteract the influence of Hindi film songs on the performance of na't in an environment saturated by Bollywood.

An enthusiastic adoption of na't audio recordings in local religious practice has also been informed by the sense that the spiritual benefit, or sawab, bestowed on the person practicing na't increases with the number of times na't is recited and listened to, granted the appropriate disposition of the listener. The observation that recorded nat enables Muslims to listen to na't, and experience its transformative effects, much more frequently than previously_by opening up new contexts of use for the genre, such as individually listening to it at home or in the car, has led to the perception that the increased electronic circulation of the genre has resulted in a multiplication of its spiritual benefits. At the same time, some fear the dangers that come with the diminished control over its use and the expansion of contexts of performance and audition. These are, above all, the blurring and crossover of nat into musical entertainment genres, such as film songs, with their associations of romantic love, and the sensual dance performances central to Hindi film productions. In fact, the soundtrack of a famous Hindi classic, Mughal-e Azam (Asif 2005 [1960]), features natt (cf. Asani 1995: 182). Any benefits of listening to and appreciating na't in these entertainment contexts, many Mauritian Muslims fear, would be corrupted and turned into their opposite, and many are concerned that the tunes of film songs have a powerful influence on the way na't is recited and performed in Mauritius. In addition, the leaking boundary between nat and popular musical genres provides support, at least in Mauritius, for the numerous detractors of the practice of na't.

\section{SAFEGUARDING THE AUTHORITY OF DEVOTIONAL PRACTICES THROUGH SOUND REPRODUCTION}

Even many Muslims affiliated with the Ahl-e Sunnat tradition in Mauritius are ready to concede that performing and listening to nat are supplementary to what are seen as essentials of Islamic practice and, thus, constituting an additional layer of piety. Their argument with Deobandi-affiliated Muslims is whether the performing of na't in a mahfil-e mawlud is an illicit innovation (bid'a), as the 
Deobandis argue, or a laudable practice bestowing additional benefits. ${ }^{11}$ An imam in the northeastern village of Plaine des Roches illustrated the latter perspective in the following way, speaking to me in his usual Mauritian Creole with heavy use of Urdu loanwords:

Why not do a little extra? Why just the bare necessities? Why go without the benefit of doing something which is not minimal obligation but otherwise recommended? One day a great 'alim said, "When the Day of Judgment [qayamat ka din] comes, God will not do justice [Allah pa pu fer insaf].” A group of maulanas [respected Muslim leaders who are graduates of Islamic institutions of learning] got together, outraged, and staged a protest, confronting their teacher. "How is it possible," they said, "that you declare God will not be just on the day of judgment?" The teacher replied, "If God would do justice on the Day of Judgment, no one would be allowed to enter paradise, everyone would be left in a hopeless position [Si zur qayamat pu fer insaf person pa pu kapav al jannat, tu pu tasse]. Think of all he has given us. He has given us so much, we would never be able to repay him. God's mercy is much greater than your worship [Allah so rahmat li boku pli gran ki u ibadat]. Therefore, why should we only do the minimum while worshipping? The more good you do, the better for you, you will receive benefits. For every minute you do this [extra] worship. you gain sawab. So we say, do all of it!"

Nevertheless, many Ahl-e Sunnat-affiliated Muslims I worked with agree that practicing na't is not a minimal obligation (farz), such as salat (the five daily prayers), and that it, therefore, constitutes an additional exercise of piety, standing in relative exteriority to those ways of interacting with God considered minimal obligations for all Muslims. Thus understood, the performance of nat adds a new dimension of mediation, a new intermediate dimension between Muslims and God. It does so by transforming the subjects' affective stances to an intercessor, who consequently facilitates their approach to God and his revealed word. But at the same time, intercessional practices, such as na't, raise the issue of straying too far from the words in which the immediate presence of God can be experienced, such as in Quranic recitation. This, of course, points to long-standing debates on issues of intercession (shafa' $a$ ) in Islamic traditions. Mauritian Muslims who side with the Deobandiaffiliated Tabliqis reject performing and listening to na't precisely because of its perceived supplementary character, which raises the specter of corruption of commended forms of worship through song, illicit innovation, and even idolatry.

The use of sound-reproduction technology can be seen as a new intervention in these old debates, which continue to divide Muslims in Mauritius, as well as in other parts of the Muslim world. For many Mauritian Muslims, religious authority and concerns about diasporic authenticity, in the sense of dealing with the temporal and spatial remove from a homeland, are closely interrelated questions. When I asked Anwar, who at the time was in his twenties and worked in a relative's construction-steel business, about the differences between listening to na't 
on cassettes and CDs and the ways nat was previously known and practiced in Mauritius, he answered,

We Muslims are a minority here, and far away from the Islamic world. We are often worried about whether what we follow is correct, with so many things: how to celebrate weddings, doing mawlud, and distributing sweets afterward. Some say yes, some no. Especially na't-many are against it and say that na' $t$ often exaggerate and describe our Prophet like God, and say that reciting in group is forbidden. We know this is wrong, but we have to be certain. Listening to great na't khwan on tapes or the radio gives us an example to follow. We could always obtain the opinion of great scholars in India or Pakistan. But with the tapes, there is better guidance and assurance. It is easier to follow the teachings of great authorities this way, even if they are far away.

A local epistemology of sound reproduction, informed by a logocentric authority of voice in religious discourse, evokes the problematic known in the literature on the political economy of globalization as "time-space compression" (Harvey 1989) or "deterritorialization" (Appadurai 1996, Tomlinson 1999; see also Castells 1996: 462-463). According to this literature, electronic mediation of discourse and images is invested with a special significance, because enabling the shrinking of spatiotemporal distances is one of the key formal properties of such forms of mediation. These concerns are relevant to my discussion because the diasporic dimension of Islamic traditions in Mauritius is important for the circulation and uses of na't through cassettes and CDs. Here, a sense that electronic circulation of na't is evidence of its genuine and authoritative status in Islamic traditions in South Asia, and even in the Arab world, is also understood in terms of diasporic authenticity. Mauritian Muslims are often concerned that living as a minority on the periphery of the Muslim world might result in their deviation from what is understood to be correct Islamic practice (cf. Lambek 1990). In other words, the spatial and temporal remove from the homeland of the immigrating Indian ancestors gives rise to concerns that authentic religious practice may gradually be lost, a worry Muslims share with many Mauritian Hindus (Eisenlohr 2006a).

There is no direct equivalence, however, between uses of sound reproduction in the circulation of na't, with its authenticating powers, and the media-facilitated experiences of time-space compression described by theorists of globalization. Instead, I suggest, the potential for a minimization of temporal and spatial distances enabled by the material frame of technologies of sound reproduction is appropriated and reworked through established logocentric epistemologies of an authority of voice. Thus, media practices recast what is often described as a hallmark formal characteristic of contemporary media: facilitating experiences of multiple spatial and time frames simultaneously in terms of a particular tradition of discourse circulation. Here, Mauritian Muslims reshape technology according to a genealogical form of Islamic authority centered on a "safeguarding" of textual and performative transmission through long successions of reliable interlocutors. 
This genealogical form of authority in the transmission of texts privileges vocal recitation over writing, because the former has a stronger link to a personal chain of transmission. Such authority has deep roots in Islamic scholarship, where in the study of hadith a text (matn) needs to be authorized by a supporting chain of reliable and morally trustworthy interlocutors (isnad), ideally reaching back to the Prophet and his companions. "Documents alone, without a line of persons possessed of both knowledge and righteousness to teach and convey them across the years, are useless as instruments of authoritative transmission. It is the 'golden chain of sincere Muslims' that guarantees faithful copying, memorizing, reciting and understanding of texts - not only those of the Hadith but those of the Qur'an and all subsequent works of Muslim piety and learning" (Graham 1993: 507, emphasis in the original; see also Brown 2009).

According to my Mauritian Muslim interlocutors, this paradigm of isnad also extends to vocally recited na't and shapes the domestication of sound reproduction into this devotional practice. In other words, what theorists of globalization describe as the shrinking of time and space afforded by technologies of electronic mediation-here, sound reproduction-is interpreted in terms of a reliable transmission of authoritative voice. As a consequence, the reproduction of vocal sound ensures the authenticity and performative force of devotional discourse and recital through long chains of transmission and circulation. This reading of what sound reproduction accomplishes also shapes the experience of listening to recorded na't as aesthetically appealing, recitationally correct, and thus, effective as a technique of intercession and accumulation of sawab. That is, na't recorded on cassettes and CDs in the particular diasporic context of Mauritius, where the contest over religious authority is also reflected in concerns about diasporic authenticity, in some measure mitigates apprehensions about too many layers of mediation between God and Muslims, because of the qualitative characteristics attributed to it as a means of voice mediation. A recitational logocentrism informing the use of na't recorded on cassettes and CDs also refutes concerns about the corruption of sacred utterances as a result of the multiple layers of mediation between pious subjects and God presupposed by practices of intercession such as na't. It counteracts the doubts about the legitimacy of performing na't as compared, for example, with the recitation of scripture. This particular articulation between mediation of voice through sound reproduction and religion understood as a practice of mediation between subjects and an otherworld, therefore, supports the claims of the followers of the Ahl-e Sunnat tradition in Mauritius in their struggle with Tabliqis and Salafis, as they make a situated use of this articulation to mitigate what are widely seen as the dangers of their practices of intercession. 